E-JURNAL EKONOMI DAN BISNIS UNIVERSITAS UDAYANA
Available online at https://ojs.unud.ac.id/index.php/EEB/index
Vol. 10 No. 01, January 2021, pages: 39-44
e-ISSN: 2337-3067

\title{
PENGARUH ROE DAN NPM TERHADAP HARGA SAHAM PERUSAHAAN SUBSEKTOR OTOMOTIF DAN KOMPONEN YANG TERDAFTAR DI BEI PERIODE 2014-2019
}

\author{
Vina Tiara Safitri ${ }^{1}$ Hari Sulistiyo ${ }^{2}$
}

Article history:

Submitted: 15 Oktober 2020

Revised: 10 Desember 2020

Accepted: 2 Januari 2021

Keywords:

$R O E$;

NPM;

Stock Price;

Kata Kunci:

$R O E$;

$N P M$;

Harga Saham;

\section{Koresponding:}

Fakultas Ekonomi

Universitas Singaperbangsa

Karawang, Jawa Barat,

Indonesia.

Email:1610631030291@stud ent.ac.id
Abstract

This study aims to determine the effect of Return On Equity (ROE) and Net Profit Margin (NPM) on the stock prices of automotive sub-sector companies and components listed on the Indonesia Stock Exchange for the period 2014-2019. Hypothesis testing in this study uses Multiple Linear Regression Analysis. In this study 13 companies, with a sample of 11 companies, the sample selected using purposive sampling. The results of this study indicate that Return On Equity and Net Profit Margin have no partial or simultaneous influence on stock prices. Based on the research results discussed earlier, it can be concluded that Return On Equity (ROE) has no effect on stock prices, Net Profit Margin (NPM) has no effect on stock prices, and it can be seen that Return On Equity (ROE) and Net Profit Margin ( NPM) does not have a simultaneous effect on stock prices in automotive and component subsector companies in 2014-2019.

\section{Abstrak}

Penelitian ini bertujuan untuk mengetahui pengaruh Return On Equity (ROE) dan Net Profit Margin (NPM) terhadap harga saham perusahaan subsektor otomotif dan komponen yang terdaftar di Bursa Efek Indonesia periode 2014- 2019. Pengujian hipotesis dalam penelitian ini menggunakan Analisis Regresi Linear Berganda.Populasi dalam penelitian ini 13 perusahaan, dengan sampel 11 perusahaan, sampel yang dipilih menggunakan purposive sampling. Hasil dari penelitian ini menunjukan bahwa Return On Equity dan Net Profit Margin tidak memiliki pengaruh secara parsial maupun simultan terhadap harga saham. Berdasarkan hasil penelitian yang telah dibahas sebelumnya, dapat disimpukan bahwa Return On Equity (ROE) tidak berpengaruh terhadap harga saham, Net Profit Margin (NPM) tidak berpengaruh terhadap harga saham, dan dapat diketahui bahwa Return On Equity (ROE) dan Net Profit Margin (NPM) tidak berpengaruh secara simultan terhadap harga saham pada perusahaan subsektor otomotif dan komponen pada tahun 2014-2019.

Fakultas Ekonomi Universitas Singaperbangsa Karawang, Jawa Barat, Indonesia ${ }^{2}$

Email: hari.sulistiyo@fe.unsika.ac.id 


\section{PENDAHULUAN}

Seiring dengan kemajuan teknologi, informasi, dan komunikasi diera globalisasi saat ini, dunia bisnis perusahaan yang semakin kompetitif harus mampu beradaptasi untuk menghindari kebangkrutan dan bersinar dalam bisnis. Untuk mengantisipasi hal ini, perusahaan harus dapat mempertahankan dan meningkatkan kinerja untuk kelangsungan bisnisnya. Salah satu cara untuk mempertahankan bisnis suatu perusahaan yaitu dengan meningkatkan modal yang dimiliki, pasar modal menjadi suatu alternatif pembiayaan untuk mendapatkan modal dengan biaya yang relatif murah dan juga tempat untuk investasi jangka pendek dan jangka panjang.

Salah satu aspek yang dinilai dalam berinvestasi yaitu kinerja keuangan, pada prinsipnya semakin baik perusahaan maka akan meningkatkan permintaan saham perusahaan tersebut, sehingga pada gilirannya akan meningkatkan pula harga saham perusahaan. Harga saham juga menggambarkan nilai dari suatu perusahaan. Ketika perusahaan mencapai prestasi yang baik, maka nilai saham perusahaan tersebut akan berdampak pada minat para investor. Harga saham terbentuk melalui mekanisme permintaan dan penawaran dipasar modal. Apabila suatu saham mengalami kelebihan permintaan, maka harga saham cenderung naik. sebaliknya, apabila kelebihan penawaran maka harga saham cenderung turun Santono (2010).

Terdapat beberapa faktor yang dapat mempengaruhi Harga Saham, diantaranya Return On Equity dan Net Profit Margin. Menurut Syamsuddin (2011) Return On Equity merupakan suatu pengukuran dari penghasilan (income) yang tersedia bagi para pemiliki perusahan (baik pemegang saham biasa maupun pemegang saham preferen) atas modal yang mereka investasikan didalam perusahaan. Semakin tinggi nilai ROE maka semakin tinggi pula harga saham. Beberapa penelitian terdahulu mengenai pengaruh Return On Equity terhadap Harga Saham terdapat hasil yang berbedabeda. Menurut Hutami (2012) dalam penelitiannya menyatakan bahwa ROE berpengaruh positif terhadap harga saham begitu pula menurut kamar (2017) Return On Equity berpengaruh positif terhadap harga saham Hasil penelitian tersebut didukung oleh penelitian Sondakh et al., (2015) menurut penelitiannya Return on Equity (ROE) berpengaruh signifikan terhadap harga saham. sedangkan menurut Pratama \& Erawati (2014) menyatakan bahwa Return On Equity (ROE) tidak mempunyai pengaruh terhadap harga saham.

Menurut Hery (2015) marjin laba bersih merupakan rasio yang digunakan untuk mengukur besarnya persentase laba bersih atas penjualan bersih. Rasio ini dihitung dengan membagi laba bersih dengan penjualan bersih. Semakin tinggi nilai NPM maka harga saham cenderung meningkat. Beberapa penelitian terdahulu mengenai pengaruh Net Profit Margin terhadap Harga Saham terdapat hasil yang berbeda-beda. Menurut Hutami (2012) menyatakan bahwa Net Profit Margin (NPM) berpengaruh positif signifikan terhadap harga saham. Sejalan dengan hasil penelitian Dewi \& Hidayat (2014) Net Profit Margin (NPM) berpengaruh positif dan signifikan terhadap harga saham. Menurut penelitian Widiawati \& Ilat (2015) menyatakan bahwa Net Profit Margin (NPM) berpengaruh signifikan terhadap harga saham. sedangkan menurut Pratama \& Erawati (2014) menyatakan bahwa Net Profit Margin (NPM) tidak mempunyai pengaruh terhadap harga saham. Hal ini di dukung oleh penelitian yang di lakukan oleh Sha (2015) menyatakan bahwa Return On Equity (ROE) dan Net Profit Margin (NPM) tidak berpengaruh signifikan terhadap harga sahamPerusahaan Manufaktur Yang Terdaftar Di Bursa Efek Indonesia tahun 2010 - 2013. Berdasarkan latar belakang tersebut dan berdasarkan inkonsistensi hasil penelitian terdahulu mengenai faktor-faktor yang mempengaruhi harga saham, maka penulis tertarik untuk melakukan penelitian mengenai "Pengaruh Return On Equity dan Net Profit Margin terhadap Harga Saham pada Perusahaan Subsektor Otomotif dan komponen yang terdaftar di BEI Periode 2014-2019”. 


\section{METODE PENELITIAN}

Metode penelitian pada dasarnya cara ilmiah untuk mendapatkan data dengan tujuan dan kegunaan tertentu Sugiyono (2017). Adapun pendekatan dalam penelitian ini yaitu metode kuantitatif karena data penelitiannya merupakan angka-angka dan analisisnya menggunakan statistik. Penelitian ini dilakukan diperusahaan subsektor otomotif dan komponen yang terdapat di BEI tahun 20142019. Populasi dalam penelitian ini sebanyak 13 perusahaan dan sampel yang digunakan sebanyak 11 perusahaan dengan menggunakan teknik purposive sampling. Data yang digunakan adalah data sekunder. Data ini merupakan data berupa laporan keuangan tahunan perusahaan subsektor Otomotif dan Komponennya periode 2014-2019 yang bersumber dari website resmi idx. Dan metode pengumpulan data menggunakan metode dokumentasi dan studi pustaka.

Hipotesis diuji menggunakan analisis regresi linear berganda dengan bantuan SPSS 22, sehingga didapatkan ppersamaan sebagai berikut :

$$
\mathrm{Y}=\alpha+\beta 1 \mathrm{X} 1+\beta 2 \mathrm{X} 2+\mathrm{e}
$$

Keterangan :

$\begin{array}{ll}\mathrm{Y} & \text { : Harga saham } \\ \alpha & \text { : konstanta } \\ \beta 1 \beta 2 & \text { : koefisien regresi variabel independen } \\ \mathrm{X} 1 & \text { : Return On Equity (ROE) } \\ \mathrm{X} 2 & \text { : Net Profit Margin }(\mathrm{NPM}) \\ \mathrm{e} & \text { : tingkat eror, tingkat kesalahan }\end{array}$

\section{HASIL DAN PEMBAHASAN}

Metode deskriptif ini memberikan gambaran suatu data mengenai masing- masing variabel pada penelitian ini. Berikut hasil uji analisis deskriptif :

Tabel 1

Hasil Analisis Statistic Deskriptif

\begin{tabular}{|c|c|c|c|c|c|}
\hline Variabel & $\mathbf{N}$ & Minimum & Maximum & Mean & $\begin{array}{l}\text { Std. } \\
\text { Deviasi }\end{array}$ \\
\hline ROE & 36 & $-1,67$ & 10,71 & 4,0278 & 3,36683 \\
\hline NPM & 36 &,- 55 & 8,17 & 2,9247 & 2,70616 \\
\hline Harga Saham & 36 & 125 & 3903 & 1372,81 & 934,828 \\
\hline
\end{tabular}

Sumber : Data diolah peneliti,2020

Dari banyaknya 11 sempel perusahaan subsektor otomotif dan komponennya variabel dependen yaitu harga saham memiliki nilai mean (rata- rata) yaitu sebesar 1372,81, nilai standar deviasi yaitu sebesar 934,828, nilai maksimum yaitu sebesar 3903, yang terdapat pada perusahaan AUTO (2014) dan memiliki nilai minimum yaitu 125 yang terdapat pada perusahaan PRAS (2015).

Variabel independen yaitu retun on equity (ROE) memiliki nilai mean (rata-rata) yaitu sebesar 4,0278, nilai standar deviasi yaitu sebesar 3,36683, nilai maksimum yaitu sebesar $10,71 \%$ yang terdapat pada perusahaan GJTL (2016) dan memiliki nilai minimum yaitu $-1,67 \%$ yang terdapat pada perusahaan GDYR (2017).

Pengaruh ROE dan NPM Terhadap Harga Perusahaan Subsektor Otomotif dan Komponen Yang Terdaftar di BEI Periode 2014-2019

Vina Tiara Safitri dan Hari Sulistiyo 
Variabel independen yaitu net profit margin (NPM) memiliki nilai mean (rata-rata) yaitu sebesar 2,9247, nilai standar deviasi yaitu sebesar 2,70616, nilai maksimum yaitu sebesar $8,17 \%$ yang terdapat pada perusahaan MASA (2014) dan memiliki nilai minimum yaitu $-0,55 \%$ yang terdapat pada perusahaan GDYR (2017).

Uji Normalitas mempunyai tujuan untuk menguji apakah dalam model regresi variabel dependen, variabel independen maupun keduanya berdistribusi normal atau tidak. Pengujian normalitas dalam penelitian ini menggunakan nonparametrik kolmogorov-smirnov, yaitu dengan ketetntuan Jika nilai Asymp.Sig. (2 tailed) > 0,05 maka data berdistribusi normal. Dan jika nilai Asymp.Sig. ( 2 tailed) < 0,05 maka data tidak berdistribusi normal. Hasil pengujian diperoleh nilai residualnya yaitu sebesar 0,117 artinya $0,117>0,05$ sehingga dapat disimpulkan data yang digunakan dalam penelitian ini berdistribusi normal. Dengan demikian uji statistik parametrik dalam penelitian ini menggunakan analisis regresi.

Tabel 2.

Hasil Uji Normalitas

\begin{tabular}{ll}
\hline & Unstandarized Residual \\
\hline $\mathrm{N}$ & 36 \\
Asymp.sig.(2-tailed) &, 117 \\
\hline
\end{tabular}

Sumber: Data diolah, 2020.

Menurut Ghozali (2016) Uji multikolonearitas bertujuan untuk menguji apakah model regresi mempunyai korelasi antar variabel bebas. Ada atau tidak multikolinieritas dalam model regresi dapat dilihat dari Variance Inflation Factor (VIF) dan nilai tolerance dengan ketentuan Jika nilai VIF $<10$ dan nilai $\mathrm{T}>0,01$ maka tidak terjadi multikolinieritas dan Jika nilai VIF $\geq 10$ dan nilai $\mathrm{T}<0,01$ maka terjadi multikolinieritas. Hasi dari uji mutikolonearitas diperoleh nilai VIF yaitu sebesar ROE 3,020 dan NPM 3,020, artinya, nilai VIF ROE 3,020 dan NPM 3,020 kurang dari 10. Dan nilai Tolerance ROE 0,331 dan NPM 0,331. Itu berarti nilai T lebih besar dari 0,01. Dengan demikian dapat disimpulkan bahwa data tersebut bebas dari uji multikolonearitas. Hasil persamaan analisis regresi linear berganda sebagai berikut :

$$
\text { Harga Saham }(\mathrm{Y})=1366,349-101,616 \mathrm{ROE}+142,148 \mathrm{NPM}+\mathrm{e} \ldots \ldots \ldots \ldots \ldots . .(2)
$$

Nilai konstanta sebesar 1366,34, hal ini menunjukan jika tidak ada perubahan variabel independen yaitu $\mathrm{ROE}(\mathrm{X} 1)$, NPM(X2) sebelumnya atau bernilai 0 (nol) maka variabel dependen yaitu harga saham akan tetap bernilai 1366,34. Koefesien regresi untuk variabel X1 yaitu ROE bernilai negatif. Hal ini menunjukan adanya hubungan tidak searah antara ROA (X1) dengan Harga Saham (Y). Koefesien regresi variabel X1 sebesar -101,616. Berarti bahwa setiap pertambahan atau kenaikan tingkat ROE (X1) sebesar satu-satuan akan menyebabkan penurunan harga saham sebesar -101,616. Koefesien regresi untuk variabel X2 yaitu NPM bernilai positif. Artinya adanya hubungan searah antara NPM (X2) dengan Harga Saham (Y). Koefesien regresi variabel X2 sebesar 142,148. Berarti bahwa setiap pertambahan atau kenaikan NPM (X2) sebesar satu-satuan akan menyebabkan kenaikan harga saham sebesar 142,148.

Pengujian hipotesis secara parsial yaitu Uji t digunakan untuk menguji hipotesis secara parsial guna menunjukan pengaruh tiap variabel independen secara individu terhadap variabel dependen. Berdasarkan hasil pengujian pada variabel ROE diperoleh nilai thitung sebesar -1,246. Jika dibandingkan dengan nilai ttabel yaitu sebesar 2,03452. Sehingga nilai thitung $-1,246<$ nilai ttabel 2,03452. Serta nilai signifikansi sebesar 0,222 lebih besar dari 0,05. Sehingga dapat disimpulkan H0 diterima dan H1 ditolak. Dengan demikian, dapat disimpulkan bahwa tidak adanya pengaruh Return On Equity terhadap harga saham.

Pengaruh ROE dan NPM Terhadap Harga Perusahaan Subsektor Otomotif dan Komponen Yang Terdaftar di BEI Periode 2014-2019 Vina Tiara Safitri dan Hari Sulistiyo 
Hasil pengujian pada variabel NPM diperoleh nilai thitung sebesar 1,401. Jika dibandingkan dengan nilai ttabel yaitu sebesar 2,03452. sehingga nilai thitung 1,401 < nilai ttabel 2,03452. Serta nilai signifikansi sebesar 0,171 lebih besar dari 0,05. Sehingga dapat disimpulkan $\mathrm{H} 0$ diterima dan $\mathrm{H} 2$ ditolak. Dengan demikian, dapat disimpulkan bahwa tidak adanya pengaruh Net Profit Margin terhadap harga saham. Berdasrkan hasil pengujian secara simultan nilai Ftabel dalam penelitian ini adalah Ftabel $=\mathrm{F}(2 ; 33)=3,2$. selanjutnya dibandingkan nilai Fhitung dengan nilai Ftabel. Sehingga diperoleh nilai $0,996<3,28$ artinya Fhitung lebih kecil dari Ftabel. Nilai signifikan senilai 0,380 lebih besar dari 0,05. Artinya tidak terdapat pengaruh, sehingga Ho diterima H3 ditolak. Dengan demikian, dapat disimpulkan bahwa tidak adanya pengaruh Return On Equity dan Net Profit Margin secara simultan terhadap harga saham.

Analisis koefisien determinasi bertujuan untuk mengukur seberapa jauh kemampuan model dalam menerangkan variabel-variabel dependen. nilai koefisien determinasi atau $\mathrm{R}^{2}$ sebesar 0,057 atau 5,7\%. Hal ini menunjukan bahwa variabel yang di teliti yaitu Return On Equity dan Net Profit Margin berpengaruh sebesar $5,7 \%$ terhadap harga saham. Sedangkan sisanya yaitu sebesar $94,3 \%$ terhadap harga saham dipengaruhi oleh variabel yang tidak diteliti dalam penelitian ini atau variabel pengganggu. Koefesien Determinasi $\left(\mathrm{R}^{2}\right)$ bertujuan untuk mengukur seberapa jauh kemampuan model dalam menerangkan variasi variabel dependen. Maka dapat dikatakan kemampuan Return On Equity dan Net Profit Margin berpengaruh sebesar 0,7\% terhadap harga saham.

Hasil analisis data membuktikan bahwa tidak adanya pengaruh Return On Equity (ROE) terhadap harga saham pada perusahaan subsektor otomotif dan komponen yang terdaftar di BEI periode 2014-2019. Hal ini dikarenakan Retun On Equity yang meningkat belum tentu memberikan minat yang tinggi pada investor dalam berinvestasi, Karena seorang investor tidak hanya melihat dari faktor ekuitas yang dimiliki perusahaan. modal yang besar dalam suatu perusahaan belum tentu menggambarkan prospek perusahaan yang baik, karena meskipun suatu perusahaan mempunyai modal yang besar tapi perusahaan tidak bisa mengelolanya secara efisien maka hal tersebut akan memberikan dampak yang buruk terhadap perusahaan tersebut, nilai modal yang tinggi yang diikuti dengan laba yang kecil maka akan menyebabkan nilai Return On Equity yang rendah, dan seorang investor akan mempertimbangkan dalam menanamkan modalnya karena bagi investor informasi mengenai peluang mengenai pengembalian atas investasi yang akan diterima lebih penting dibanding dengan kempuan perusahaan dalam menghasilkan laba.

Hasil penelitian ini sejalan dengan penelitian yang dilakukan oleh Pratama \& Erawati (2014) menyatakan bahwa Return On Equity (ROE) tidak mempunyai pengaruh terhadap harga saham pada Perusahaan Manufaktur Yang Terdaftar Di Bursa Efek Indonesia Periode 2008-2011. Pengaruh NPM terhadap Harga Saham membuktikan bahwa tidak adanya pengaruh Net Profit Margin terhadap harga saham pada perusahaan subsektor otomotif dan komponen yang terdaftar di BEI periode 2014-2019. Hal ini dikarenakan Net Profit Margin yang meningkat belum tentu memberikan minat yang tinggi pada investor dalam berinvestasi, Karena seorang investor tidak hanya melihat dari faktor penjualan yang dilakukan perusahaan. penjualan yang tinggi dalam suatu perusahaan belum tentu menggambarkan prospek perusahaan yang baik, karena meskipun suatu perusahaan mencapai penjualan yang tinggi tapi perusahaan tidak bisa menekan biaya-biaya perusahaan maka hal tersebut akan memberikan dampak yang buruk terhadap perusahaan tersebut, nilai penjualan yang tinggi yang diikuti dengan biaya-biaya yang tinggi maka akan menyebabkan nilai Net Profit Margin yang rendah, dan seorang investor akan mempertimbangkan dalam menanamkan modalnya karena bagi investor informasi mengenai peluang mengenai pengembalian atas investasi yang akan diterima lebih penting dibanding dengan kempuan perusahaan dalam menghasilkan laba. Hasil penelitian ini sejalan dengan penelitian Pratama \& Erawati (2014) menyatakan bahwa Net Profit Margin (NPM) tidak mempunyai pengaruh terhadap harga saham pada Perusahaan Manufaktur Yang Terdaftar Di Bursa Efek Indonesia Periode 2008-2011.

Pengaruh ROE dan NPM Terhadap Harga Perusahaan Subsektor Otomotif dan Komponen Yang Terdaftar di BEI Periode 2014-2019 Vina Tiara Safitri dan Hari Sulistiyo 


\section{SIMPULAN DAN SARAN}

Berdasarkan hasil penelitian yang telah dibahas sebelumnya, dapat disimpukan bahwa Return On Equity (ROE) tidak berpengaruh terhadap harga saham, Net Profit Margin (NPM) tidak berpengaruh terhadap harga saham, dan dapat diketahui bahwa Return On Equity (ROE) dan Net Profit Margin (NPM) tidak berpengaruh secara simultan terhadap harga saham pada perusahaan subsektor otomotif dan komponen pada tahun 2014-2019.

Saran bagi perusahaan disarankan sebaiknya lebih mampu mengontrol dan mengelola ekuitas maupun penjualan perusahaan. selain perusahaan juga harus mampu mengefisiensikan tingkat biaya yang terjadi diperusahaan agar dapat menghasilkan laba yang diinginkan. Karena semakin besar tingkat laba bersih, maka daya tarik investor semakin meningkat. Bagi para investor disarankan dalam memprediksi dan menghitung harga saham sebaiknya mempertimbangkan faktor- faktor internal maupun eksternal perusahaan sebelum menanamkan modalnya. Agar dapat memberikan informasi yang lebih relevan dan meyakini sebagai dasar acuan dalam bagaimana cara memprediksi harga saham. Dan Bagi peneliti selanjutnya diharapkan dapat meneliti faktor lainnya yang dapat mempengaruhi harga saham. sehingga hasil penelitian tersebut bisa diperbandingkan dengan hasil penelitian penulis.

\section{REFERENSI}

Alalwan, A. A., Dwivedi, Y. K., Rana, N. P., \& Algharabat, R. (2018). Examining factors influencing Jordanian customers' intentions and adoption of internet banking: Extending UTAUT2 with risk. Journal of Retailing and Consumer Services, 40, 125-138.

Alharbi, N., Papadaki, M., \& Dowland, P. (2017). The impact of security and its antecedents in behaviour intention of using e-government services. Behaviour \& Information Technology, 36(6), 620-633.

Brown, S. A., \& Venkatesh, V. (2005). Model of Adoption of Technology in Households: A Baseline Model Test and Extension Incorporating Household Life Cycle. MIS Quarterly, 399-426.

Dewi, S. P., \& Hidayat, R. (2014). Pengaruh Net Profit Margin dan Return on Assets terhadap Harga Saham pada Perusahaan Otomotif yang Terdaftar di Bursa Efek Indonesia. ILMAN. 01(1). 1-10.

Ghozali, I. (2016). Aplikasi Analisis Multivariete IBM SPSS. In Semarang, Universitas Diponegoro.

Hery. (2015). Analisis Kinerja Manajemen. In PT Gramedia Widiasarana Indonesia.

Hutami, R. P. (2012). Pengaruh Dividen Per Share, Return On Equity dan Net Profit Margin Terhadap Harga Saham Perusahaan Industri Manufaktur Yang Tercatat Di Bursa Efek Indonesia Periode 2006-2010. Nominal, Barometer RisetAkuntansi Dan Manajemen. 01(2). 104-123.

Kamar, K. (2017). Analysis of the Effect of Return on Equity (Roe) and Debt to Equity Ratio (Der) On Stock Price on Cement Industry Listed In Indonesia Stock Exchange (Idx) In the Year of 2011-2015. IOSR Journal of Business and Management. 19(05). 66-76.

Pratama, A., \& Erawati, T. (2014). Pengaruh Current Ratio, Debt To Equity Ratio,Return On Equity, Net Profit Margin Dan Earning Per Share Terhadap Harga

Santono, A. (2010). Manajemen Keuangan Teori. In BPFE.

Sha, T. L. (2015). Pengaruh Kebijakan Dividen, Likuiditas, Net Profit Margin , Return on Equity, Dan Price To Book Value Terhadap Harga Saham Pada Perusahaan. Jurnal Akuntansi. 19(2). 276-294.

Sondakh, F., Tommy, P., \& Mangantar, M. (2015). URRENT RATIO, DEBT TO EQUITY RATIO, RETURN ON ASSET, RETURN ON EQUITY PENGARUHNYA TERHADAP HARGA SAHAM PADA INDEKS LQ 45 DI BEI PERIODE 2010-2014. Jurnal EMBA: Jurnal Riset Ekonomi, Manajemen, Bisnis Dan Akuntansi. 03(2). 749-756.

Sugiyono. (2017). MetodePenelitian Kuantitatif, Kualitatif dan R\&D. Bandung: PT Alfabet.

Syamsuddin, L. (2011). Manajemen Keuangan Perusahaan: Konsep Aplikasi dalam: Perencanaan, Pengawasan, dan Pengembaian Keputusan. Jurnal Administrasih Bisnis.

Widiawati., W. R., \& Ilat, V. (2015). pengaruh return on asset (ROA), net profit margin (NPM), dan earning per share (EPS) terhadap harga saham pada perushaan perbankan di bursa efek indonesia periode 20112015. Akuntansi Biaya \& Keuangan. 4(02). 518-529. 